\title{
HUBUNGAN KEJADIAN MELASMA DENGAN PENGGUNAAN KONTRASEPSI HORMONAL SUNTIK DAN PIL KOMBINASI DI BPM DWI ASTUTIK, DESA PETUNGSEWU, DAU, KABUPATEN MALANG
}

\author{
Fauqo Wildatil Jannah ${ }^{1 *}$, Dewi Ariani ${ }^{2,}$ Yuseva Sariati $^{3}$ \\ ${ }^{1}$ Program Studi S1 Kebidanan, FakultasKedokteran, Universitas Brawijaya, \\ Email* $^{*}$ fauqowildaa@gmail.com \\ HP : +6281333199686
}

\begin{abstract}
Melasma is a hyperpigmentation arising due to the buildup of melanin in the epidermis, dermis, or both. Melasma can appear on the users of hormonal contraceptives such as the pill or injection combination and tend to appear on face areas so that it can be influencing the life's quality. The appearance of melasma on the user of injection and pill combination is affected by the presence of estrogen and progesterone hormones which is contained in contraception and it will cause kind of accumulation in the body. Estrogen and progesterone hormones are interrelated in affecting cells pigmentation, as one of melanocyte's receptor. The difference of hormonal substances can give different influence to the genesis of melasma. This research aims to know the correlation between melasma occurrence with the use of injection combination of hormonal contraceptives and pills combination in Dwi Astutik Maternity Home, Petungsewu Village in Dau District of Malang Regency. The research design was used the case-control sampling technique using a purposive sampling technique. The number of respondents as many as 34 people, on each group (case and control). Data analysis using the Chi-Square Test and obtained the value of $\alpha=0.015$ (significant) and the odds ratio of 3.378. The conclusion of this study is there is a correlation between injection and pill combination and the genesis of melasma. the use of injection combination 3.378 times is riskier to emerge melasma than the use of pill combination.
\end{abstract}

Keywords: Hormonal Contraception, Injection Combination, Combination Pills, Melasma

\begin{abstract}
ABSTRAK
Peningkatan penggunaan kontrasepsi hormonal di Indonesia berhubungan dengan beberapa keuntungan yang diberikan, seperti efektif, murah, dan terjangkau berbagai kalangannamun terdapat salah satu efek samping yang dianggap merugikan bagi penggunanya, yaitu melasma. Melasma adalah hiperpigmentasi yang ditimbulkan akibat adanya penumpukan melanin pada
\end{abstract}


epidermis, dermis, maupun keduanya. Melasma dapat muncul pada pengguna kontrasepsi hormonal seperti pil kombinasi maupun suntik kombinasi, dan sering muncul pada area wajah sehingga hal ini dapat mempengaruhi kualitas hidup sehari- hari. Munculnya melasma pada pengguna pil dan suntik kombinasi dipengaruhi oleh adanya hormon estrogen dan progesteron yang terkandung dalam kontrasepsi tersebut yang akan mengakibatkan penumpukan di dalam tubuh. Hormon estrogen dan progesteron saling berkaitan dalam mempengaruhi pigmentasi sel, dimana mereka berperan secara langsung pada melanosit sebagai salah satu reseptornya. Kandungan hormon yang berbeda dapat memberikan pengaruh yang berbeda pula pada kejadian melasma. Penelitian ini bertujuan untuk mengetahui hubungan kejadian melasma dengan penggunaan kontrasepsi hormonal suntik kombinasi dan pil kombinasi di BPM Dwi Astutik Desa Petungsewu Kecamatan Dau Kabupaten Malang. Desain penelitian yang digunakan adalah desain case control dengan teknik pengambilan sampel menggunakan teknik purposive sampling. Jumlah responden sebanyak 34 orang, pada tiap kelompok (kasus dan kontrol). Analisis data menggunakan Uji ChiSquare dan diapatkan nilai $\alpha=0,015$ (signifikan) dan odd ratio sebesar 3,378. Kesimpulan pada penelitian ini adalah terdapat hubungan pada penggunaan kontrasepsi hormonal suntik kombinasi dan pil kombinasi dengan kejadian melasma dengan besar resiko yaitu penggunaan suntik kombinasi 3,378 kali lebih beresiko menimbulkan melasma dibanding penggunaan pil kombinasi.

Kata kunci: Kontrasepsi Hormonal, Suntik Kombinasi, Pil Kombinasi, Melasma

*Korespondensi: Fauqo Wildatil Jannah. Surel: fauqowildaa@gmail.com 


\section{PENDAHULUAN}

Penggunaan kontrasepsi dapat dijadikan salah satu alat untuk menekan jumlah penduduk serta meningkatkan kesehatan ibu dan anak. Pemerintah mencanangkan penggunaan alat kontrasepsi untuk pengaturan kehamilan dikarenakan menurut World Population Data Sheet 2013, Indonesia merupakan negara ke-5 di dunia dengan jumlah penduduk terbanyak, yaitu sekitar 249 juta jiwa dan memiliki Angka Fertilitas atau Total Fertility Rate (TFR) 2,6, hal ini menempatkan Indonesia berada di posisi di atas rata- rata negara ASEAN yaitu sekitar 2,4. ${ }^{1}$

Saat ini banyak tersedia metode atau alat kontrasepsi baik itu kontrasepsi hormonal maupun non hormonal. Pada tahun 2013, jumlah cakupan peserta KB aktif secara nasional sekitar $75,88 \%$, dimana cakupan peserta KB aktif di wilayah Jawa Timur sebesar 76,54\%. ${ }^{1}$ Pengguna KB aktif di Kabupaten Malang pada tahun 2016 sekitar 352, 283 jiwa, dengan Jenis kontrasepsi yang paling banyak digunakan oleh peserta KB aktif adalah jenis suntik sebesar $50,13 \%$ kemudian diikuti oleh kontrasepsi pil sebanyak $19,00 \%{ }^{2}$

Peningkatan penggunaan kontrasepsi hormonal berhubungan dengan fungsinya yang efektif, murah, dan mudah dijangkau berbagai kalangan. Terlepas dari keberhasilan maupun keuntungan yang diperoleh dari penggunaan kontraepsi hormonal pasti memiliki efek samping jika digunakan dalam kurun waktu yang lama. Hal ini dikarenakan adanya kandungan hormon dalam kontrasepsi yang dapat merubah sistem kerja tubuh.Salah satu efek samping yang ditimbulkan dari kontrasepsi hormonal adalah terjadinya melasma. Munculnya melasma pada pengguna kontrasepsi hormonal pil dan suntik kombinasi sering mempengaruhi kualitas hidup sehari- hari. Melasma sering muncul pada area wajah sehingga hal ini mudah terlihat. ${ }^{3}$ Hal ini dapat menjadi dilema karena disisi lain mereka menginginkan pola haid yang teratur sehingga mereka menggunakan jenis kontrasepsi kombinasi namun mereka juga merasa terbebani dengan adanya melasma sebagai salah satu efek yang ditimbulkan.

Melasma dapat dipengaruhi oleh penggunaan kontrasepsi hormonal jenis kombinasi baik itu pil maupun suntik, namun, derajat keparahan yang ditimbulkan berbeda. Munculnya melasma pada pengguna kontrasepsi hormonal seperti pil kombinasi dan suntik kombinasi diakibatkan karena adanya penumpukan hormon estrogen dan progesteron dalam tubuh. Hormon estrogen yang terkandung dalam kontrasepsi tersebut dapat berperan secara langsung pada melanosit sebagai salah satu reseptornya, hal ini dapat mempengaruhi pigmentasi kulit, sedangkan efek hormon progesteron yang terkandung pada kontrasepsi hormonal dapat mempengaruhi melanin untuk meningkatkan penyebarannya di dalam sel. ${ }^{4,5}$

Berdasarkan penelitian, pada sekitar $40-50 \%$ wanita penderita melasma, hal ini dipicu karena kehamilan atau penggunaan kontrasepsi oral. ${ }^{4}$ Penelitian lain menunjukkan pada sekitar 148 orang menggunakan kontrasepsi pil, 24 menggunakan suntik hormonal, 
dan 6 orang menggunakan kontrasepsi patch. Beberapa orang menggunakan lebih dari satu jenis kontrasepsi, dan sisanya tidak memberikan informasi. Hasilnya, sekitar $25 \%$ wanita yang menggunakan kontrasepsi hormonal mengaku bahwa kejadian melasma muncul setelah mereka menggunakan kontrasepsi hormonal tersebut. 6

Bidan Praktik Mandiri (BPM) Dwi Astutik berada di Desa Petungsewu yang merupakan salah satu desa yang terletak di Kecamatan Dau Kabupaten Malang, dimana terdapat banyak akseptor aktif KB hormonal pil kombinasi dan suntik kombinasi yang melakukan pengobatan di BPM tersebut. Berdasarkan studi pendahuluan yang dilakukan peneliti, didapatkan $70 \%$ dari 10 pengguna kontrasepsi hormonal mengalami melasma. Banyaknya keluhan mengenai melasma akibat penggunaan kontrasepsi hormonal jenis kombinasi membuat penulis tertarik untuk melakukan penelitian mengenai hubungan kejadian melasma dengan penggunaan kontrasepsi hormonal suntik kombinasi dan pil kombinasi yang akan dilakukan di BPM Dwi Astutik, Desa Petungsewu, Kecamatan Dau, Kabupaten Malang.

Tujuan Penelitian ini adalah untuk mengetahui hubungan kejadian melasma dengan penggunaan kontrasepsi hormonal suntik kombinasi dan pil kombinasi di BPM Dwi Astutik Desa Petungsewu Kecamatan Dau Kabupaten Malang.

Penelitian ini dilakukan dengan menggunakan akseptor KB suntik kombinasi dan pil kombinasi yang menderita melasma dan yang tidak menderita melasma. Kemudian akan dibandingkan untuk mengetahui kontrasepsi mana yang dapat memeberikan efek samoing lebih besar terhadap timbulnya melasma. Penelitian ini menggunakan rekam medis sebagai instrumen penelitian untuk mengetahui jenis kontrasepsi yang digunakan, lama penggunaan, serta data lain yang dapat menunjang penelitian ini sesuai dengan tujuan ppenelitian.

\section{METODE PENELITIAN}

\section{Rancangan/Desain Penelitian}

Rancangan penelitian yang digunakan adalah observasional analitik dengan metode penelitian case control.

Variabel Penelitian

Variabel yang digunakan dalam penelitian ini adalah:

- Variabel bebas (Independent variable) adalah penggunaan kontrasepsi hormonal suntik kombinasi dan pil kombinasi

- Variabel terikat (dependent variable) adalah melasma.

\section{Sumber Data}

Data dalam penelitian ini menggunakan dua seumber data yaitu data primer yang diperoleh langsung dari responden seperti observasi wajah untuk melihat melasma, pengisian lembar skrining sampling serta wawancara langsung pada responden, kemudian data sekunder yang diperoleh dari kartu status peserta KB juga data yang dimiliki oleh pihak BPM.

\section{Sasaran Penelitian}

Populasi dari penelitian ini adalah seluruh akseptor kontrasepsi hormonal di BPM Dwi Astutik, Desa Petungsewu, Kecamatan Dau, 
Kabupaten Malang. Sampel yang bertindak sebagai kasus pada penelitian ini adalah wanita yang menderita melasma dan menjadi akseptor kontrasepsi hormonal serta memenuhi kriteria inklusi dan eksklusi. Kontrol pada penelitian ini adalah wanita yang tidak menderita melasma dan menjadi akseptor kontrasepsi hormonal serta memenuhi kriteria inklusi dan eksklusi.Jumlah sampel dalam penelitian ini adalah 68 responden, dengan pembagian 34 responden untuk kelompok kasus, yaitu yang menderita melasma dan 34 responden untuk kelompok kontrol, yaitu yang tidak menderita melasma yang dipilih berdasarkan teknik purposive sampling sesuai dengan kriteria inklusi dan eksklusi.

\section{Pengembangan Instrumen dan Teknik Pengumpulan Data}

Instrumen penelitian yang digunakan peneliti dalam penelitian ini adalah Kartu Status Peserta KB, data pasien di BPM, alat tulis, lembar observasi, dan lembar skrining sampel serta melakukan observasi pada responden untuk mengetahui kejadian melasma.

\section{Teknik Analisis Data}

Analisis data dilakukan dalam beberapa tahap, yang pertama adalah analisis univariat untuk mengetahui distribusi ukuran kasus sampel tiap variabel. Kemudian melakukan analisis bivariat untuk mengetahui besar pengaruh faktor resiko kontrasepsi hormonal suntik kombinasi dan pil kombinasi terhadap kejadian melasma. Data yang sudah diolah dilakukan analisis dengan menggunakan uji Chisquare test $\left(\mathrm{x}^{2}\right)$ dengan interpretasi besar pengaruh dinyatakan menggunakan Odds Ratio (OR) dengan Confidence Interval (Cl) sebesar $95 \%$ dan toleransi kesalahan $5 \%(\alpha=0,05)$.

$$
\text { Penelitian ini telah }
$$

mendapatkan persetujuan etik dari komisi etik Fakultas Kedokteran Universitas Brawijaya dengan nomor 290/EC/KEPK-S1$\mathrm{KB} / 08 / 2017$.

\section{HASIL PENELITIAN}

Peneliti mengambil responden sesuai dengan kriteria inklusi dan eksklusi yang telah ditetapkan peneliti dan diperoleh 34 responden untuk kelompok kasus dan 34 responden untuk kelompok kontrol.

\section{Karakteristik Kejadian Melasma Berdasarkan Usia}

Tabel 5.1 Distribusi Frekuensi Kejadian Melasma pada Pengguna Kontrasepsi Hormonal Suntik Kombinasi dan Pil Kombinasi Berdasarkan Usia

\begin{tabular}{|c|c|c|c|c|c|c|c|c|}
\hline \multirow{3}{*}{$\begin{array}{l}\text { Usia } \\
\text { (th) }\end{array}$} & \multicolumn{4}{|c|}{ Melasma } & \multicolumn{4}{|c|}{ Tidak Melasma } \\
\hline & \multicolumn{2}{|c|}{$\begin{array}{c}\text { Suntik } \\
\text { Kombinasi }\end{array}$} & \multicolumn{2}{|c|}{$\begin{array}{c}\text { Pil } \\
\text { Kombinasi }\end{array}$} & \multicolumn{2}{|c|}{$\begin{array}{c}\text { Suntik } \\
\text { Kombinasi }\end{array}$} & \multicolumn{2}{|c|}{$\begin{array}{c}\text { Pil } \\
\text { Kombinasi }\end{array}$} \\
\hline & $\mathrm{n}$ & $\mathrm{P}$ & $\mathrm{n}$ & $\mathrm{P}$ & $\mathrm{n}$ & $\mathrm{P}$ & $\mathrm{n}$ & $\mathrm{P}$ \\
\hline$\leq 19$ & 1 & $3 \%$ & 0 & $0 \%$ & 3 & $9 \%$ & 0 & $0 \%$ \\
\hline $\begin{array}{c}20- \\
29\end{array}$ & 9 & $26 \%$ & 4 & $12 \%$ & 7 & $21 \%$ & 11 & $32 \%$ \\
\hline $\begin{array}{c}30- \\
39\end{array}$ & 12 & $35 \%$ & 7 & $21 \%$ & 3 & $9 \%$ & 10 & $29 \%$ \\
\hline$\geq 40$ & 1 & $3 \%$ & 0 & $0 \%$ & 0 & $0 \%$ & 0 & $0 \%$ \\
\hline & 23 & $67 \%$ & 11 & $33 \%$ & 13 & $39 \%$ & 20 & $61 \%$ \\
\hline Total & \multicolumn{2}{|c|}{$\mathrm{n}: 34$} & \multicolumn{2}{|c|}{$P: 100 \%$} & \multicolumn{2}{|c|}{$\mathrm{n}: 34$} & P: 10 & $\%$ \\
\hline
\end{tabular}

Ket: $\mathrm{n}=$ Jumlah; $\mathrm{P}=$ Persentase

Berdasarkan tabel 5.1 maka jumlah responden yang menderita 
melasma sebagian besar berada pada rentang usia 30-39 tahun yaitu sebesar $56 \%$ atau sebesar 19 responden, yang terdiri dari 12 akseptor suntik kombinasi dan 7 akseptor pil kombinasi. Kemudian sebesar $38 \%$ atau 13 responden yaitu 9 akseptor suntik kombinasi dan 4 akseptor pil kombinasi, berada pada rentang usia 20-29 tahun, serta responden yang berusia $\leq 19$ tahun dan $\geq 40$ tahun yaitu sebesar $3 \%$ atau masing masing terdapat 1 responden, yaitu terdapat pada akseptor suntik kombinasi.

Berdasarkan tabel 5.1 maka jumlah responden yang tidak menderita melasma sebagian besar berada pada rentang usia 20-29 tahun yaitu sebesar $53 \%$ atau sebesar 18 responden, yaitu terdiri dari 7 akseptor suntik kombinasi dan 11 akseptor pil kombinasi. Kemudian sebesar $38 \%$ atau 13 responden berada pada rentang usia 30-39 tahun yang terdiri dari 3 akseptor suntik kombinasi dan 10 akseptor pil kombinasi, serta responden yang berusia $\leq 19$ tahun sebesar 9\% atau sebanyak 3 responden yaitu akseptor suntik kombinasi, sedangkan responden yang berusia $\geq 40$ tahun yaitu sebesar $0 \%$ atau tidak ada.

\section{Karakteristik Kejadian Melasma Berdasarkan Usia}

Tabel 5.2 Distribusi Frekuensi Kejadian Melasma pada Pengguna Kontrasepsi Hormonal Suntik Kombinasi dan Pil Kombinasi Berdasarkan Lama Penggunaan

\begin{tabular}{|c|c|c|c|c|}
\hline \multirow{2}{*}{$\begin{array}{c}\text { Lama } \\
\text { Penggu } \\
\text { naan }\end{array}$} & \multicolumn{2}{|c|}{ Melasma } & \multicolumn{2}{|c|}{ Tidak Melasma } \\
\hline & $\begin{array}{l}\text { Suntik } \\
\text { Kombi }\end{array}$ & $\begin{array}{c}\text { Pil } \\
\text { Kombi }\end{array}$ & $\begin{array}{l}\text { Suntik } \\
\text { Kombi }\end{array}$ & $\begin{array}{c}\text { Pil } \\
\text { Kombi }\end{array}$ \\
\hline
\end{tabular}

\begin{tabular}{|c|c|c|c|c|c|c|c|c|}
\hline & \multicolumn{2}{|c|}{ nasi } & \multicolumn{2}{|c|}{ nasi } & \multicolumn{2}{|c|}{ nasi } & \multicolumn{2}{|c|}{ nasi } \\
\hline & $\mathrm{n}$ & $P$ & $\mathrm{n}$ & $P$ & $\mathrm{n}$ & $P$ & $n$ & $P$ \\
\hline 6 bulan & 2 & $\begin{array}{l}6 \\
\%\end{array}$ & 1 & $\begin{array}{l}3 \\
\%\end{array}$ & 5 & $\begin{array}{l}15 \\
\%\end{array}$ & 6 & $\begin{array}{l}18 \\
\%\end{array}$ \\
\hline $\begin{array}{l}>6-24 \\
\text { bulan }\end{array}$ & $\begin{array}{l}1 \\
3\end{array}$ & $\begin{array}{l}38 \\
\%\end{array}$ & 9 & $\begin{array}{l}26 \\
\%\end{array}$ & 7 & $\begin{array}{l}21 \\
\%\end{array}$ & $\begin{array}{l}1 \\
2\end{array}$ & $\begin{array}{l}35 \\
\%\end{array}$ \\
\hline $\begin{array}{l}>24 \\
\text { bulan }\end{array}$ & 8 & $\begin{array}{l}24 \\
\%\end{array}$ & 1 & $\begin{array}{l}3 \\
\%\end{array}$ & 1 & $\begin{array}{l}3 \\
\%\end{array}$ & 3 & $\begin{array}{l}9 \\
\%\end{array}$ \\
\hline \multirow{2}{*}{ Total } & $\begin{array}{l}2 \\
3\end{array}$ & $\begin{array}{l}68 \\
\%\end{array}$ & $\begin{array}{l}1 \\
1\end{array}$ & $\begin{array}{l}32 \\
\%\end{array}$ & $\begin{array}{l}1 \\
3\end{array}$ & $\begin{array}{l}39 \\
\%\end{array}$ & $\begin{array}{l}2 \\
1\end{array}$ & $\begin{array}{l}61 \\
\%\end{array}$ \\
\hline & & $\begin{array}{r}\text { ר: } 34 \\
10\end{array}$ & & & & $\begin{array}{r}34 \\
10\end{array}$ & & $P:$ \\
\hline
\end{tabular}

Berdasarkan tabel 5.2 lama penggunaan terbanyak berada penderita melasma berada pada rentang $>6-24$ bulan yaitu sebesar $65 \%$ atau sebesar 22 responden, terdiri dari 13 akseptor suntik kombinasi dan 9 akseptor pil kombinasi. Kemudian sebesar $26 \%$ atau sebanyak 9 responden yang terdiri dari 8 akseptor suntik kombinasi dan 1 aksepor pil kombinasi, telah menggunakan selama $>24$ bulan, dan sebesar $9 \%$ atau sebanyak 3 responden telah menggunakan selama 6 bulan, yaitu 2 pada akseptor suntik kombinasi dan 1 pada akseptor pil kombinasi.

Berdasarkan tabel 5.2 lama penggunaan terbanyak berada pada rentang $>6-24$ bulan yaitu sebesar $56 \%$ atau sebanyak 19 responden, terdiri dari 7 akseptor suntik kombinasi dan 12 akseptor pil kombinasi, kemudian sebesar $32 \%$ atau sebanyak 11 responden telah menggunakan selama 6 bulan, terdiri dari 5 askeptor suntik kombinasi dan 6 akseptor pil kombinasi, dan sebesar $12 \%$ atau sebanyak 4 responden, terdiri dari 1 akseptor suntik kombinasi dan 3 
akseptor pil kombinasi, telah menggunakan selama $>24$ bulan.

Distribusi Frekuensi Responden Berdasarkan Kejadian Melasma dan Non Melasma

Tabel 5.3 Distribusi Frekuensi reponden Berdasarkan Kejadian Melasma dan Non Melasma

\begin{tabular}{ccc}
\hline $\begin{array}{c}\text { Kelompok } \\
\text { Responden }\end{array}$ & Jumlah & Presentase \\
\hline Melasma & 34 & $50 \%$ \\
\hline $\begin{array}{c}\text { Tidak } \\
\text { Melasma }\end{array}$ & 34 & $50 \%$ \\
\hline Total & 68 & $100 \%$ \\
\hline
\end{tabular}

Berdasarkan tabel 5.3 tersebut diperoleh data bahwa frekuensi responden yang mengalami melasma yaitu sebanyak 34 responden atau $50 \%$, sedangkan frekuensi responden yang tidak mengalami melasma yaitu sebanyak 34 responden atau $50 \%$ dari jumlah total responden yaitu 68 responden.

\section{Distribusi Frekuensi Responden Berdasarkan Penggunaan Suntik Kombinasi dan Pil Kombinasi}

Tabel 5.4 Distribusi Frekuensi Reponden Berdasarkan Penggunaan Kontrasepsi Hormonal Sunik Kombinasi dan Pil Kombinasi

\section{Berdasarkan tabel 5.4} diperoleh data bahwa jumlah responden yang menggunakan kontrasepsi hormonal suntik kombinasi sebanyak 36 responden atau $53 \%$, sedangkan responden yang menggunakan kontrasepsi hormonal pil kombinasi, yaitu sebanyak 32 responden atau $47 \%$.

\section{Perbandingan Penggunaan Kontrasepsi Hormonal Suntik Kombinasi dan Pil Kombinasi dengan Kejadian Melasma}

Tabel 5.5 Analisis Bivariat Faktor Resiko Kontrasepsi Hormonal Suntik Kombinasi dan Pil Kombinasi dengan Kejadian Melasma

\begin{tabular}{|c|c|c|c|c|c|c|}
\hline $\begin{array}{l}\text { Faktor } \\
\text { Resiko }\end{array}$ & & asm & & $\begin{array}{l}\text { lak } \\
\text { asm }\end{array}$ & \multirow[b]{2}{*}{ OR } & \multirow[b]{2}{*}{$P$} \\
\hline $\begin{array}{c}\text { Kontrase } \\
\text { psi } \\
\text { Hormona } \\
\text { । }\end{array}$ & $n$ & $P$ & $n$ & $P$ & & \\
\hline $\begin{array}{c}\text { Suntik } \\
\text { Kombina } \\
\text { si }\end{array}$ & $\begin{array}{l}2 \\
3\end{array}$ & $\begin{array}{c}33, \\
8 \\
\%\end{array}$ & $\begin{array}{l}1 \\
3\end{array}$ & $\begin{array}{c}19, \\
2 \\
\%\end{array}$ & $\begin{array}{c}(\mathrm{Cl} \\
95 \%) \\
3,\end{array}$ & \\
\hline $\begin{array}{c}\text { Pil } \\
\text { Kombina } \\
\text { si }\end{array}$ & $\begin{array}{l}1 \\
1\end{array}$ & $\begin{array}{c}16, \\
2 \\
\%\end{array}$ & $\begin{array}{l}2 \\
1\end{array}$ & $\begin{array}{c}30 \\
9 \\
\%\end{array}$ & $\begin{array}{c}378 \\
(1,24 \\
6-\end{array}$ & $\begin{array}{c}0,01 \\
5\end{array}$ \\
\hline Total & $\begin{array}{l}3 \\
4\end{array}$ & $\begin{array}{l}50 \\
\%\end{array}$ & $\begin{array}{l}3 \\
4\end{array}$ & $\begin{array}{l}50 \\
\%\end{array}$ & ) & \\
\hline
\end{tabular}

Pada penelitian ini didapatkan 34 responden pada kelompok kasus dan 34 responden pada kelompok kontrol. Pada kelompok kasus, terdapat 23 akseptor kontrasepsi hormonal suntik kombinasi yang menderita melasma dan 11 akseptor

\begin{tabular}{ccc}
\hline $\begin{array}{c}\text { Kelompok } \\
\text { Responden }\end{array}$ & Jumlah & Presentase \\
\hline $\begin{array}{c}\text { Pengguna } \\
\text { Suntik } \\
\text { Kombinasi }\end{array}$ & 36 & $53 \%$ \\
\hline $\begin{array}{c}\text { Pengguna Pil } \\
\text { Kombinasi }\end{array}$ & 32 & $47 \%$ \\
\hline Total & 68 & $100 \%$
\end{tabular}

kontrasepsi hormonal pil kombinasi 
yang menderita melasma. Pada kelompok kontrol, terdapat 13 akseptor kontrasepsi hormonal suntik kombinasi yang tidak mengalami melasma dan 21 akseptor kontrasepsi hormonal pil kombinasi yang tidak mengalami melasma.Hasil analisis dengan uji Chi- Square didapatkan nilai $p$ sebesar 0,015 yang berarti penggunaan kontrasepsi hormonal suntik kombinasi secara statistik memiliki hubungan yang bermakna dengan kejadian melasma. Odds Ratio sebesar 3, 378 dengan 95\% Interval Kepercayaan:1,246 < 3, 378 $<9,157$ menunjukkan bahwa suntik kombinasi merupakan faktor resiko terjadinya melasma, reponden yang menggunakan kontrasepsi hormonal suntik kombinasi mempunyai resiko 3,378 kali lebih besar menderita melasma dibanding pengguna kontrasepsi hormonal lainnya seperti pil kombinasi. Berdasarkan tabel 5.5 maka dapat disimpulkan bahwa $\mathrm{HO}$ ditolak dan $\mathrm{H} 1$ diterima, dimana terdapat hubungan antara penggunaan kontrasepsi hormonal suntik kombinasi dengan kejadian melasma.

\section{Distribusi Frekuensi Derajat Keparahan Melasma pada Penggunaan Kontrasepsi Hormonal Suntik Kombinasi dan Pil Kombinasi}

Tabel 5.6 Distribusi Frekuensi Derajat Keparahan Melasma dengan

Penggunaan Kontrasepsi Hormonal Suntik Kombinasi dan Pil Kombinasi

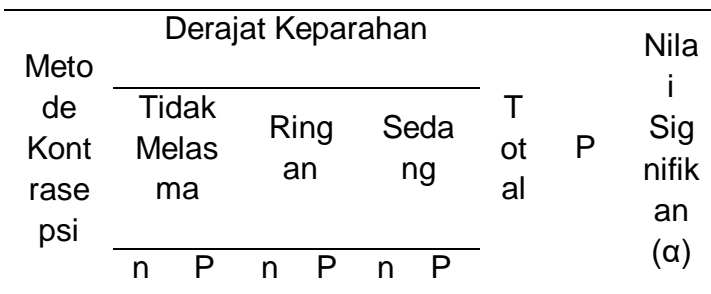

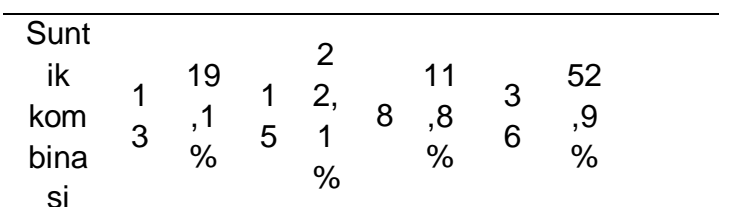

\begin{tabular}{cccccccccc}
\hline Pil & & 30 & & 1 & & & & 47 & 0,0 \\
kom & 2 & 9 & 1 & 6, & 0 & 0 & 3 &, 1 & 01 \\
bina & 1 &, 9 & 1 & 2 & 0 & $\%$ & 2 & $\%$ & \\
si & & $\%$ & & $\%$ & & & & $\%$ &
\end{tabular}

\begin{tabular}{ccccccccc}
\hline \multirow{5}{*}{ Total } & 3 & 50 & 2 & 8, & & 11 & 6 & 10 \\
& 4 & $\%$ & 6 & 2 & 8 &, 8 & 8 & 0 \\
& & & & $\%$ & & $\%$ & & $\%$
\end{tabular}

Berdasarkan tabel 5.6 pada pengguna suntik kombinasi terdapat 13 responden atau $19,1 \%$ tidak mengalami melasma, 15 responden atau $22,1 \%$ berada pada kategori ringan, dan 8 responden atau $11,8 \%$ berada pada kategori sedang, sedangkan pada pengguna pil kombinasi terdapat 21 responden atau $30,9 \%$ yang tidak mengalami melasma dan 11 responden atau $16,2 \%$ berada pada kategori ringan. 


\section{PEMBAHASAN \\ Karakteristik Responden}

Berdasarkan hasil penelitian pada wanita penderita melasma dan tidak melasma yang menggunakan kontrasepsi hormonal, mayoritas berusia antara 30- 39 tahun. Hubungan usia dalam pemakaian KB berperan sebagai faktor intrinsik dimana hal ini juga berkaitan dengan teori yang menyebutkan bahwa usia melahirkan terbaik bagi istri adalah umur 20- 30 tahun, sehingga mayoritas responden pengguna kontrasepsi berusia diatas 30 tahun dengan tujuan untuk menunda kehamilan atau bahkan untuk menghentikan kehamilan. Umur > 35 tahun merupakan kurun reproduksi tua sehingga dianjurkan untuk tidak hamil karena jika terjadi kehamilan dapat meningkatkan angka kesakitan dan kehamilan beresiko tinggi. Notoadmodjo berpendapat bahwa hal yang dapat mempengaruhi perilaku seseorang dalam penggunaan kontrasepsi salah satunya adalah usia. Namun peningkatan usia bukan menjadi alasan utama seseorang untuk menggunakan kontrasepsi, karena terdapat faktor lain yang mempengaruhi seperti jumlah anak yang dapat menjadi pertimbangan penting dalam penggunaan alat kontrasepsi. $7,8,9$

Hasil penelitian menunjukkan bahwa lama penggunaan kontrasepsi hormonal sebagian besar responden berada pada rentang >6- 24 bulan. Lama pemakaian kontrasepsi tergantung dari tujuan responden apakah untuk menjarangkan kehamilan atau untuk mengakhiri kehamilan. Terlepas dari kerugian yang ditimbulkan, keuntungan yang dapat diperoleh responden dari penggunaan kontrasepsi hormonal seperti suntik kombinasi dan pil kombinasi, diantaranya tidak berpengaruh pada hubungan suami istri, dapat dijadikan kontrasepsi jangka panjang, dan mudah dalam penatalaksanannya membuat responden merasa nyaman dalam menggunakan kontrasepsi hormonal ini. Pada rentang waktu $<2$ tahun, efek samping dari penggunaan kontrasepsi hormonal belum sepenuhnya muncul sehingga responden lebih merasakan keuntungan yang ditimbulkan dari pada kerugian dari penggunaan kontrasepsi hormonal. ${ }^{10,8}$

\section{Hubungan Kejadian Melasma dengan Penggunaan Kontrasepsi Hormonal Suntik Kombinasi dan Pil Kombinasi}

Berdasarkan hasil penelitian diperoleh data bahwa melasma dapat muncul pada responden yang menggunakan kontrasepsi hormonal, seperti suntik kombinasi dan pil kombinasi. Responden yang mengalami melasma dan merupakan pengguna kontrasepsi hormonal suntik kombinasi sebanyak 23 responden, dan 13 responden tidak mengalami melasma. Sedangkan askeptor kontrasepsi hormonal lain dalam hal ini adalah pengguna pil kombinasi, yang mengalami melasma sebanyak 11 responden dan yang tidak mengalami melasma sebanyak 21 responden. Tidak hanya pengguna suntik kombinasi yang dapat menderita melasma melainkan pengguna kontrasepsi hormonal lain seperti pil kombinasi juga berpeluang untuk menderita melasma, karena selain penggunaan kontrasepsi hormonal, melasma juga dapat dipengaruhi oleh faktor lain, seperti hal nya usia 
akseptor maupun lama penggunaan dari kontrasepsi hormonal tersebut. Berdasarkan usia, kejadian melasma pada akseptor suntik kombinasi muncul mayoritas pada usia 30- 39 tahun, begitu juga pada akseptor pil kombinasi yang mayoritas menderita melasma berada pada rentan usia 30- 39 tahun. Hal ini juga sesuai dengan teori yang menyebutkan bahwa kejadian melasma terbesar pada rentan usia 30- 44 tahun. Menurunnya fungsi tubuh untuk melakukan regenerasi sel dapat menjadi pemicu melasma mudah muncul pada rentan usia tersebut, sehingga terjadi hambatan dalam pembentukan pigmen serta pengangkatan melanin berlebih. Faktor lain yang dapat mempengaruhi timbulnya melasma adalah lama penggunaan, dimana lama penggunaan dari kontrasepsi hormonal juga berperan pada pembentukan melasma, penggunaan selama 6 bulan secara rutin sudah dapat menimbulkan terjadinya melasma. Hal ini sesuai dengan penelitian yang dilakukan Asih (2012) yang menyebutkan bahwa melasma dapat muncul pada pemakaian jangka waktu 6 bulan 2 tahun. Pada pemakaian kontrasepsi hormonal >24 bulan prevalensinya lebih kecil dari pemakaian >6- 24 bulan. Hal ini dapat terjadi sehubungan dengan penyebab melasma yang multifaktoral, tergantung dari interaksi hormonal dalam tubuh dan juga ketahanan terhadap substrat genetik, sehingga tidak hanya disebabkan oleh salah satu faktor saja, meskipun dalam kasus ini penggunaan kontrasepsi hormonal berpengaruh besar terhadap timbulnya melasma. ${ }^{11,12}$ Oleh karena itu, diduga pada kelompok pemakaian $>6$ - 24 bulan memiliki faktor resiko yang lebih kompleks daripada pemakai yang lebih dari 24 bulan.

Perbandingan hasil analisis bivariat secara keseluruhan dapat dilihat pada tabel 5.3 dimana uji signifikansi dengan menggunakan Chi- Square diperoleh nilai $p$ sebesar 0, 015 (signifikansi $(p)<$ $0,05)$. Hal ini berarti terdapat hubungan antara penggunaan kontrasepsi hormonal suntik kombinasi dan pil kombinasi dengan kejadian melasma. Nilai Odds Ratio yang dihasilkan sebesar 3,378 dengan interval kepercayaan 95\%: $1,246<3,378<9,157$. Nilai ini menunjukkan bahwa responden kontrasepsi hormonal suntik kombinasi mengalami resiko untuk mengalami kejadian melasma sebesar 3,378 kali lebih tinggi dari pada responden yang menggunakan kontrasepsi hormonal lain, dalam hal ini adalah pil kombinasi.

Penggunaan kontrasepsi hormonal suntik kombinasi beresiko lebih besar untuk menimbulkan melasma dibanding penggunaan pil kombinasi, dengan besar resiko yaitu 3 kali lebih beresiko. Hal ini dapat terjadi salah satunya disebabkan oleh lebih besarnya kandungan hormon estrogen maupun progesteron yang terkandung di dalam kontrasepsi suntik kombinasi dibanding dengan pil kombinasi. Hal ini sesuai dengan teori yang menyatakan bahwa hiperpigmentasi dapat terbentuk akibat adanya stimulasi melanogenesis oleh hormon estrogen dan progesteron. Efek biologis yang ditimbulkan oleh hormon estrogen dan progesteron 
dimediasi oleh reseptor yang berbeda. Aktivitas estrogen dan progesteron termediasi oleh reseptor yang terekspresi pada kulit, yaitu estrogen receptor- alpha (Era), Er- $\beta$, dan reseptor progesteron (PRs). Melanogenesis diawali dengan proses oksidasi asam aminotirosin menjadi Ldihidroksifenilalanin (L- DOPA) untuk kemudian menjadi dopakuinon. Tahap ini dipercepat dengan bantuan enzim tirosinase yang merupakan tahap kritis dalam melanogenesis. Proses selanjutnya yaitu polimerisasi dari dopakuinon menjadi melanin. Estrogen dapat merangsang melanogenesis pada kultur melanosit manusia dengan menginduksi sintesis dari enzim melanogenik seperti tirosinase, tyrosinase- related protein- 1 (Trp1), dan Trp-2 juga aktivitas tirosinasi pada perkembangan melanosit manusia normal. Apabila terdapat peningkatan jumlah hormon estrogen maupun progesteron dalam tubuh maka akan mempengaruhi percepatan proses melanogenesis. Terdapat sejumlah penelitian lain yang menyatakan hasil yang cukup konsisten terkait keterlibatan estrogen untuk memicu terjadinya melasma dan adanya hasil yang tidak konsisten pada keterlibatan progesteron sebagai pemicu timbulnya melasma. Terdapat adanya perbedaan eskpresi reseptor estrogen antara lesi melasma dan kulit normal, dimana pada lesi melasma ditemukan ekspresi reseptor estrogen yang lebih tinggi dibandingkan dengan kulit normal. Penelitian lain menjelaskan bahwa peran estrogen pada kejadian melasma yaitu estrogen dapat meningkatkan jumlah melanin dalam sel, sedangkan progesteron memiliki peran untuk meningkatkan persebaran melanin dalam sel. ${ }^{13,6,14,4,15}$

Hasil penelitian ini dapat diperkuat dengan teori atau penelitian terdahulu yang menunjukkan bahwa penggunaan kontrasepsi hormonal merupakan salah satu faktor etiologi dari melasma, dan adanya pigmentasi mewakili efek samping kutaneous yang paling umum terjadi akibat kontrasepsi hormonal, dimana terdapat $5-34 \%$ individu dapat terpengaruh. ${ }^{16}$ Pada penelitian yang dilakukan oleh Achar (2011) menunjukkan bahwa penggunaan kontrasepsi hormonal memicu terjadinya melasma. Hal ini dapat terlihat dari 312 responden, terdapat $18,4 \%$ wanita mengalami melasma, dan mereka juga merupakan pengguna kontrasepsi hormonal. ${ }^{17}$ Menurut Ortonne (2009), dimana terdapat 148 wanita pengguna kontrasepsi oral, 24 wanita pengguna kontrasepsi suntik, dan 6 wanita menggunakan kontrasepsi patch, serta beberapa subjek menggunakan lebih dari satu tipe kontrasepsi hormonal dan yang lain tidak memberi informasi terkait jenis kontrasepsi. Berdasarkan data tersebut didapatkan $25 \%$ wanita yang menggunakan kontrasepsi hormonal mengaku bahwa melasma muncul setelah penggunaan kontrasepsi hormonal tersebut. ${ }^{6}$

Penelitian ini juga menunjukkan derajat keparahan melasma yang ditimbulkan oleh penggunaan kontrasepsi hormonal suntik kombinasi. Mayoritas responden pengguna kontrasepsi hormonal suntik kombinasi berada pada kategori ringan jika dihitung menggunakan skor MASI, yaitu 
sebanyak 15 responden atau $22,1 \%$. Penentuan derajat keparahan dapat digunakan sebagai salah satu alat untuk dapat dilakukannya penatalaksanaan lebih lanjut sesuai dengan kebutuhan pasien, seperti tindakan suportif pada fisik maupun psikis pasien, ataupun dalam pengambilan keputusan dan kebijakan perawatan. Melasma dapat mempengaruhi kualitas hidup seseorang, dimana hal ini sesuai dengan penelitian yang dilakukan oleh Hadiyati (2004) yang menyatakan bahwa semakin tinggi derajat keparahan melasma maka semakin besar pula pengaruh terhadap kualitas hidup responden. Wanita yang terkena melasma akan mencari berbagai cara untuk dapat menghilangkan melasma yang ada di wajahnya, karena melasma akan menurunkan tingkat kepercayaan diri mereka ketika bersosialisasi dengan lingkungan. Sebagian besar wanita akan berusaha untuk tampil sempurna di hadapan publik sehingga mereka tidak ingin terganggu oleh adanya melasma yang nantinya dapat mengurangi kualitas hidup mereka dan pengaruh terbesar yang akan terjadi adalah hubungan personal dari pasien, seperti mereka akan menghindari interaksi sosial bahkan dengan teman dekat atau partner. ${ }^{18,19,20}$

\section{SIMPULAN}

$\begin{array}{cr}\text { Penelitian } & \text { ini } \\ \text { menunjukkan bahwa secara }\end{array}$ bermakna penggunaan kontrasepsi hormonal suntik kombinasi dan pil kombinasi memberikan pengaruh positif terhadap kejadian melasma pada akseptor KB di BPM Dwi Astutik Desa Petungsewu Kecamatan Dau Kabupaten Malang dengan besar resiko penggunaan suntik kombinasi yaitu 3,378 kali lebih beresiko menimbulkan kejadian melasma daripada penggunaan kontrasepsi hormonal pil Kombinasi

\section{DAFTAR PUSTAKA}

\section{REFERENSI}

1. Kemenkes. 2014. Peningkatan Kesehatan Ibu dan Anak. Jakarta: Pusat Promosi Kesehatan Kementerian Kesehatan Republik Indonesia. http://promkes. depkes.go.id/dl/lembar\%20balik\%2 Oposkesdes.pdf.

2. Kemenkes. $2014 . \quad$ Situasi Kesehatan Ibu. Jakarta: Pusat Data dan Informasi - Kementerian Kesehatan Republik Indonesia. http://www.depkes.go.id/ folder/view/01/structure-publikasipusdatin-info-datin.html

3. Kemenkes. 2010. Pedoman Pelayanan Antenatal Terpadu. Jakarta: Direktorat Jenderal Bina Kesehatan Masyarakat Kementerian Kesehatan Republik Indonesia.

http://perpustakaan.depkes.go.id:81 80/bitstream//123456789/202 4/2/BK2010-456.pdf

4. Kemenkes. 2010. Pedoman Pemantauan Wilayah Setempat Kesehatan Ibu Dan Anak (PWS$K I A)$. Jakarta: Direktorat Jenderal Bina Kesehatan Masyarakat \& Direktorat Bina Kesehatan lbu Kementerian Kesehatan Republik Indonesia.

http://www.gizikia.depkes.go.id/wpcontent/uploads/downloads/2013/08 /Pedo man-PWS-KIA.pdf.

5. Kemenkes. 2013. Buku Saku Pelayanan Kesehatan lbu di Fasilitas Kesehatan Dasar dan Rujukan. Jakarta: Kementerian Kesehatan Republik Indonesia. http://www.gizikia.depkes.go.id/wpcontent/uploads/downloads/2013/12 
/Buku -Saku-Pelayanan-KesehatanIbu.pdf

6. Kemenkes. 2013. Profil Kesehatan Indonesia $2012 . \quad$ Jakarta: Kementerian Kesehatan Republik Indonesia.

http://www.depkes.go.id/resources/ download/ pusdatin/profilkesehatan-indonesia/profilkesehatan-indonesia-2012.pdf

7. Agustini, S. 2012. Pengetahuan lbu Hamil tentang Tanda-Tanda Bahaya Kehamilan di Wilayah Kerja UPT Puskesmas Cimandala Kecamatan Sukaraja Kabupaten Bogor Tahun 2012. Skripsi. Diterbitkan, Fakultas Kesehatan Masyarakat Universitas Indonesia, Depok.

lib.ui.ac.id/file?file=digital/20314706 -S Sri\%20Agustini.pdf

8. Pembe, Andrea B., Urasso, D.P., Carlsted, A., Lindmark, G., Nystrapq, L., Darj. 2011. Rural Tanzanian Women's Awarness of DANGER Sign of Obstetric Complication. Basic data Proquest health and medicine complete

9. Kartika, E.Y. 2012. Hubungan Pengetahuan lbu Hamil Trimester III tentang Tanda Bahaya Kehamilan dengan Kepatuhan ANC di wilayah Kerja Puskesmas Lerep Kecamatan Ungaran. Semarang: Akademi Kebidanan Ngudi Waluyo

10. Meko, M.Y.D. 2012. Faktor-Faktor yang Berhubungan dengan Pengetahuan Suami tentang Tanda Bahaya pada Masa Kehamilan, Persalinan dan Nifas di Wilayah Kerja Puskesmas Bakunase tahun 2011. Kupang: FKM Undana

11. Widiantari, N.K.N. 2015. Hubungan Karakteristik lbu dan Dukungan Sosial Suami Dengan Partisipasi Ibu Mengi kuti Kelas Ibu Hamil Di Kota Denpasar. Tesis. Diterbitkan, Magister IImu Kesehatan Masyarakat, Universitas Udayana, Denpasar. http://www.pps. unud.ac.id/thesis/pdf thesis/unud-
152 3-77867673tesis\%20\%20nopi\%20\% 20fix.pdf

12. Sulyani, P. 2013. Hubungan Karakte ristik lbu Hamil dengan Pengetahuan lbu Hamil terhadap Tanda-Tanda Bahaya Kehamilan di Puskesmas Bandar Kabupaten Bener Meriah. Banda Aceh: Stikes Ubudiyah

13. Astuti, H.P. 2011. Hubungan Karakteristik lbu Hamil dengan Tingkat Pengetahuan tentang Tanda Bahaya pada Kehamilan di Puskesmas Sidoharjo Kabupaten Sragen. Jurnal Stikes Kusuma Husada Surakarta, hal. 1-13. http://digilib.stikeskusumahusa da.ac.id/files/disk1/3/01-gdltriwulanda - 119-1-tri wula-i.pdf

14. Sukesih. 2012. Faktor-Faktor yang Berhubungan dengan Pengetahuan Ibu Hamil Mengenai Tanda Bahaya dalam Kehamilan di Puskesmas Tegal Selatan Kota Tegal Tahun 2012. Skripsi. Diterbitkan, Fakultas Keseha tan Masyarakat Universitas Indonesia, Depok. lib.ui.ac.id/file?file=digital/203 15113-S Sri\%20Sukesih.pdf

15. Wulandari, R. 2014. Hubungan Tingkat Pendidikan Ibu Hamil dengan Pengetahuan Tanda Bahaya Kehami lan pada Trimester III di RB Harapan Bunda Surakarta. Surakarta: STIK PKU Muhammadiyah. http://digilib. stikespku.ac. id/ download.php?id=76. 